\title{
Alterations in cytoskeletal and immune function-related proteome profiles in whole rat lung following intratracheal instillation of heparin
}

\author{
Amir A Gabr ${ }^{1}$, Mathew Reed ${ }^{2}$, Donna R Newman ${ }^{1}$, Jan Pohl2 ${ }^{2}$ Jody Khosla ${ }^{1}$ \\ and Philip L Sannes*1
}

Address: ${ }^{1}$ Department of Molecular Biomedical Sciences, Center for Comparative Molecular Medicine and Translational Research, College of Veterinary Medicine, North Carolina State University, Raleigh, NC, USA and ${ }^{2}$ Microchemical and Proteomics Facility, Winship Cancer Institute, School of Medicine, Emory University, Atlanta, GA, USA

Email: Amir A Gabr - amirgabr@gmail.com; Mathew Reed - mreed01@emory.edu; Donna R Newman - donna_newman@ncsu.edu; Jan Pohl - jpohl@emory.edu; Jody Khosla - jody_khosla@ncsu.edu; Philip L Sannes* - philip_sannes@ncsu.edu

* Corresponding author

Published: 8 May 2007

Respiratory Research 2007, 8:36 doi:10.1 186/1465-9921-8-36
Received: 12 January 2007

Accepted: 8 May 2007

This article is available from: http://respiratory-research.com/content/8/I/36

() 2007 Gabr et al; licensee BioMed Central Ltd.

This is an Open Access article distributed under the terms of the Creative Commons Attribution License (http://creativecommons.org/licenses/by/2.0), which permits unrestricted use, distribution, and reproduction in any medium, provided the original work is properly cited.

\begin{abstract}
Background: Heparin has been shown to modify fundamental biologic processes ranging from blood coagulation and cell proliferation to fibrogenesis and asthma. The goal of this study was to identify specific or broad biologic responses of the rat lung to intratracheal instillation of heparin by targeted proteomic analysis.
\end{abstract}

Methods: Rats were given either aerosolized $500 \mu \mathrm{g}$ heparin in $250 \mu \mathrm{l}$ saline or saline alone. Lungs were harvested at 0,24 , or 96 hours post-treatment and isolated proteins analyzed by twodimensional gel electrophoresis. Proteins which increased and decreased significantly in treated groups above controls were then selected for identification by mass spectrometry.

Results: Although heparin treatments resulted in a general reduction in cytosolic protein expression, there were significant increases within members of discrete groups of proteins. At 24 hours, proteins which function in cytoskeletal organization and in calcium signaling were upregulated between 2 - and 27 -fold above baseline and untreated controls. Increased proteins include annexins $\mathrm{V}$ and $\mathrm{VI}$, septin 2, capping $\mathrm{G}$ protein, actin-related protein 3, moesin, RhoGDP dissociation inhibitor, and calcyclin. A group of proteins relating to immune response and tumor suppressor function were either up-regulated (tumor suppressor p30/hyaluronic acid binding protein-I, Parkinson disease protein 7, proteosome 28 subunit/interferon- $\gamma$ inducible protein, and proteosome subunit macropain $\alpha-1$ ) or strongly down-regulated (transgelin). At 96 hours, most proteins that had increased at 24 hours remained elevated but to a much lesser degree.

Conclusion: These cumulative observations demonstrate that whole lung heparin treatment results in significant up-regulation of selected groups of proteins, primarily those related to cytoskeletal reorganization and immune function, which may prove to be relevant biomarkers useful in analysis of lung exposures/treatments as well as in system biology studies. 


\section{Background}

Proteomic studies performed on whole organs can provide a useful, broader perspective from which to view a biological event $[1,2]$. As applied to the lung, this approach may provide important information on functional groups of proteins, a prerequisite for systems biology studies, while supporting dynamic modeling. Ultimately, pulmonary function or its disturbance can be thought of as the result of the interactions of a dynamic group of proteins originating from a diverse population of cells varying in, activation states and levels of maturity, which collectively constitute the lung proteome [3]. Heparin, a model heparan sulfate proteoglycan (HSPG), has been previously shown to reduce or inhibit proliferation and gene and protein expression in isolated rat lung type II alveolar cells [4-6]. Similarly, heparin and/or heparan sulfate have been shown to reduce proliferation in lung fibroblasts [7-9] and lung smooth muscle cells $[10,11]$. The current proteomic study was undertaken to expand investigation into the effects of heparin-like molecules on whole lung, in vivo. Normal lung contains large amounts of HSPGs, many of which are heavily sulfated. Syndecan, an HSPG spanning the cytoplasmic membrane, has a sulfated ectodomain comprised of a portion of the core protein and a variable number of glycosaminoglycan (GAG) side chains that can be enzymatically shed, both constitutively at low levels and at much higher levels during inflammation and tissue remodeling [12]. Heparin's anti-coagulant activity is well established, but more recently it has been appreciated for its antiproliferative effects, as noted above, which can prevent lung damage due to hypoxia [11], bleomycin-induced fibrosis [13] and cancer [14]. These effects have been shown to be a function of the sulfated nature of these molecules, as desulfated or otherwise modified forms are not as effective [4$6,9,10]$. Heparin has also been shown clinically to inhibit specific asthmatic responses in humans and prevent bronchoconstriction in exercise-induced asthma by mechanisms not fully understood [15-17]. It has been used experimentally as a model component of extracellular matrix and cell surface shedding [4-6,16].

The goal of this study was to identify specific proteomic responses of normal rat lungs exposed to aerosolized heparin using 2-dimensional gel electrophoretic separation and mass spectrometry (MS). Proteins so defined could then serve as potential biomarkers or indicators of responses to changes in the lung macro- and/or microenvironments that might be expected to increase during cell surface ectodomain shedding as in injury or disease, in the context of a lung systems biology approach. Although it is not intended to serve as a complete catalogue of the whole rat lung proteome, the results could be a useful reference to future proteomic studies on rat lung.

\section{Methods \\ In-vivo heparin treatments}

Two groups of specific-pathogen-free (SPF) rats were used in this study. The first group, analyzed as preliminary data for the subsequent study, consisted of Fischer rats $(n=9)$ (Charles River, Wilmington, MA) in 3 groups of 3 animals each: untreated controls, heparin-treated and sacrificed after 24 hours, and heparin-treated and sacrificed after 96 hours.

The second group consisted of Fischer rats $(n=15)$ (Harlan, Indianapolis, IN) in 5 subgroups of 3 animals each: untreated, saline/vehicle control 24 hours, heparintreated 24 hours, saline/vehicle control 96 hours, and heparin-treated 96 hours. One untreated control (baseline/reference) was sacrificed at 0, 24, and 96 hours. Vehicle controls and heparin-treated animals were sacrificed at 24 and 96 hours.

Rats weighing between 250 and 285 grams were given intraperitoneally a mixture of $30 \mathrm{mg}$ Ketaset (Fort Dodge, Fort Dodge, IA) and 6 mg X-ject (Burns Veterinary Supply, Inc., Westbury, NY) to induce anesthesia $15 \mathrm{~min}$ prior to intratracheal administration of a single aerosolized dose $(250 \mu \mathrm{l})$ of normal saline or of a $2 \mathrm{mg} / \mathrm{ml}$ solution of high molecular weight heparin, 13,500-15,000 MW, (Calbiochem, San Diego, CA) using a MicroSprayer intratracheal aerosolizer (Penn-Century, Philadelphia, PA) to optimize the distribution of heparin throughout the lung. According to the manufacturer, this generates $25-30 \mu \mathrm{m}$ sized particles, which should be capable of reaching first order (primary) bronchioles. At 24 hours or 96 hours post-treatment, the experimental and control animals were euthanized with an overdose of sodium pentobarbital. The lungs were perfused with saline until white to remove blood and minimize albumin interference in later procedures, then surgically removed from the pulmonary cavity. Pulmonary airways (visible bronchi) were separated by blunt dissection from the parenchyma (small airways and alveolar regions) and the latter flash frozen in liquid nitrogen and stored at $-80^{\circ} \mathrm{C}$ for later analysis. In some cases, the apical lobe of the right lung was tied off and insufflated with $2 \%$ paraformaldehyde in $0.1 \mathrm{M}$ phosphate buffered saline for 1 hour. Sections were dehydrated with graded alcohols and infiltrated with xylenes followed by paraffin. Paraffin embedded tissue blocks were cut into $7 \mu \mathrm{m}$ sections on a standard microtome and prepared for routine histology or immunostaining. Rabbit antiannexin V (FL-319; sc-8300, Santa Cruz Biotech, Santa Cruz, CA) was applied at 1:100 dilutions overnight and the antigen-antibody complex visualized with a VectaStain Elite Peroxidase kit (Vector Laboratories, Burlingame, CA). 


\section{Protein sample preparation}

Frozen lung parenchyma was pulverized using a specialized mortar and pestle (Fisher Scientific, Suwanee, GA) under liquid nitrogen. Equal amounts $(250 \mathrm{mg}$ ) of powdered lung were suspended in a urea-containing buffer containing $20 \mu \mathrm{g} / \mathrm{ml}$ RNase-A, $100 \mu \mathrm{g} / \mathrm{ml}$ DNase-1 inhibitor (Invitrogen, Carlsbad, CA), 1\% ampholytes ( $\mathrm{pH} 3-$ 10 ), and $50 \mu \mathrm{M}$ dithiothreitol (BioRad, LaJolla, CA). Protein concentrations were measured by chemiluminescence using Protein EZ-Quant (Invitrogen), with $100 \mu \mathrm{g}$ total lung lysate loaded per gel. All samples were diluted in 6.25 $\mathrm{M}$ urea and $2.3 \mathrm{M}$ thiourea buffer to a concentration of $1 \mathrm{mg} / \mathrm{ml}$ and stored frozen at $-80^{\circ} \mathrm{C}$. First-dimensional Readystrips, pH 5-8, $11 \mathrm{~cm}$ (BioRad) were used for all samples based on preliminary data that suggested the majority of dynamically regulated proteins focused between $\mathrm{pH} 5$ and $\mathrm{pH}$ 8. Samples were applied to strips and equilibrated for 12 hours at $50 \mathrm{~V}$ on a Protean X IEF focuser (BioRad). Samples were isoelectrically focused at $250 \mathrm{~V}$ for 15 minutes. Voltage was increased by two $500 \mathrm{~V}$ ramp increases until achieving $1500 \mathrm{~V}$, held at $1500 \mathrm{~V}$ for 2 hours, and then increased in rapid steps to $8000 \mathrm{~V}$ until complete isoelectric focus was achieved at $55 \mathrm{kVH}$.

\section{Second-dimension electrophoresis and staining}

Bis-Acrylamide gels (12.5\%) with stackers (4\%) were hand-cast in a $16 \mathrm{~cm} \times 18 \mathrm{~cm}$ gel slab Multicasting System (Hoefer Scientific, Cambridge, MA). Gels were allowed to polymerize overnight with n-butanol overlays. Firstdimension electrofocused strips were alkylated in $0.25 \%$ iodoacetamide (BioRad) for 20 minutes on an orbital shaker, rinsed with $1 \times$ Tris-Glycine-SDS running buffer, and then carefully laid onto second-dimension gels. A layer of $0.5 \%$ agarose containing bromophenol blue was poured to keep strips in place. Multiple gels were run simultaneously (to minimize group run variation) at 200 $\mathrm{V}$ for 6 hours, rinsed for 1 minute in $250 \mathrm{ml}$ of ultra-pure water twice, and fixed overnight in 10\% methanol, 5\% glacial acetic acid on a horizontal shaker. Gels were incubated in Sypro-Ruby stain (Molecular Probes, Carlsbad, $\mathrm{CA}$ ) in the dark for 16 hours.

\section{Image capture and analysis}

Gel images were captured with an Epi Chemi UVP scanner supported by a 16 bit CCD camera for enhanced high resolution images (Biolmaging Systems, Upland, CA). Aperture width and exposure time were adjusted so that only the most abundant spots on the gels reached saturation (pixel intensity was determined by the software). In addition, gels were normalized based on total protein fluorescence per gel as well as reference spot fluorescence comparison. The same settings were used for all gels. Acquired gel images were analyzed using PDQuest software (BioRad), transformed to adsorption images (dark spots against light background), cropped, and size- adjusted across all images. The effects of occasional streaking were minimized by during the analysis with the application of Guassian equations to the raw images with the PDQuest software. Spot detection parameters were optimized on a single gel representative of each individual sample, then normalized among the sub-group, and finally normalized across groups. Areas of interest were assigned to the program for further magnification. Images in each set were matched and a representative map was generated for each individual and subsequently for each sub-group per time point. Correlation coefficients of variance were calculated for each spot within sub-groups and compared with the mean correlation coefficient of variance in the software program, which then assigned significance values to each spot. Only spots with optical densities that were significantly changed by heparin (based on the Mann-Whitney statistical technique) were further analyzed for the purposes of this study.

\section{Spot selection, digestion, and protein analysis}

After selection of the most dynamically-regulated spots, gel plugs were manually excised from replicate gels $(\mathrm{n}=$ 3 ), placed in a 96-well plate, trypsin-digested overnight on an automated digester, and placed on zip-plates (Millipore Bioscience, Bedford, MA) to remove any salts that could adversely affect results. Bovine albumin was added to the Maldi plate as a positive control for MS detection. Replicate samples and control proteins were resuspended in $5 \mu \mathrm{l}$ of $30 \%$ acetonitrile/ $0.1 \%$ trifluoroacetic acid. One $\mu \mathrm{l}$ of each sample was spotted twice, allowing the spot to air dry completely each time. Matrix (alpha-cyano-4hydroxycinnamic acid, Agilent Technologies, Palo Alto, CA) $(0.5 \mu \mathrm{l})$ was overlaid on each spot. An ABI-4700 Proteomics Analyzer MALDI-time of flight/time of flight (TOF/TOF) mass spectrometer (Applied Biosystems, Foster City, CA) was used for the analysis. The instrument was set to acquire an initial MS spectrum followed by up to 15 MS/MS spectra for each spot. The instrument was internally calibrated using a mixture of 6 peptides. A default "plate" calibration was performed based upon 6 calibration spots distributed on the plate, resulting in accuracies better than $100 \mathrm{ppm}$. For the analysis of sample spots, the instrument attempted to perform an internal calibration for the individual spots using the tryptic autodigest fragments, which resulted in accuracies better than 20 ppm. If the instrument was unable to perform the internal calibration, the default "plate" calibration was applied to the sample spot. The MS and MS/MS data were processed by GPS Explorer, version 2.0 (Applied Biosystems), and submitted to our in-house MASCOT search engine (Matrix Science). The NCBI non-redundant database was searched with tolerances set to $150 \mathrm{ppm}$ for the MS spectra and 0.5 $\mathrm{kDa}$ for the MS/MS spectra. GPS Explorer then processed the search results from MASCOT. 


\section{Results}

\section{Lung histology}

Tissues prepared for morphologic examination indicated no gross or microscopic alterations in lung architecture due to the instillation of heparin at any of the time points examined (Figs. 1A-D).

\section{Preliminary experiment analysis}

Initially, 4128 spots were detected within the preliminary data set using PDQuest software and liberal parameters. Parameters of very high stringency in combination with a most conservative threshold then allowed the software to reassign 1682 spots for comparison. The software identified 551 differentially-expressed (increased/decreased) proteins, not all of which were obvious to the unaided eye. Of those, 54 protein spots were selected as the highest priority candidates based on the magnitude of change in expression and were further analyzed by mass spectrometry.

Particularly large or diffuse spots, such as those likely containing multiple proteins or representing albumin and/or transferrin, were not considered good candidates for quantitative analysis by MS and were excluded from further analysis.

\section{Controlled experiment analysis}

Across the controlled experiment data set, 3103 spots were detected using the software at liberal parameters.
With more stringent parameters, the software reassigned 942 spots for further comparison. Technical stringency indicated almost identical protein migration patterns (Figs. 2A-D) between experiments (especially Heparin treatments), hence achieving a higher degree of analytical confidence. Next, the software was able to identify 377 differentially-expressed proteins within the spots, which were again examined in a hierarchical manner.

\section{Analysis of combined experiments}

There were no visual or analytical differences between untreated, saline 24 hours, and saline 96 hours sub-group samples (CV\% range of $0.01-0.1$ ). Comparisons by the imaging software of images from replicate samples within experimental subgroups (CV\% of 0.05) and between maps of untreated controls and vehicle control groups indicated no statistically-significant differences (within $95 \%$ confidence levels). The repeatability of patterns between sub-groups enabled reliable statistical analysis of changes in protein expression/spot detection, as demonstrated in Figure 2A-D. Images with equivalent statistical strengths across replicates within subgroups were aligned to generate reference templates per subgroup which were stacked a second time across trials to generate per group templates/reference maps. Combining these images generated a single template per group with a higher confidence interval. (i.e. if a spot is in the template, it is found in all members of that subgroup). This resulted in a given protein spot being more heavily weighted statistically and

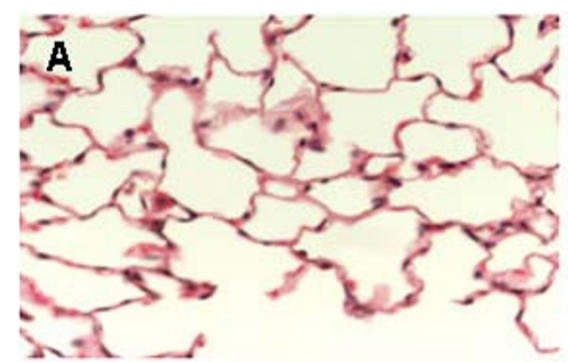

Saline 24hr

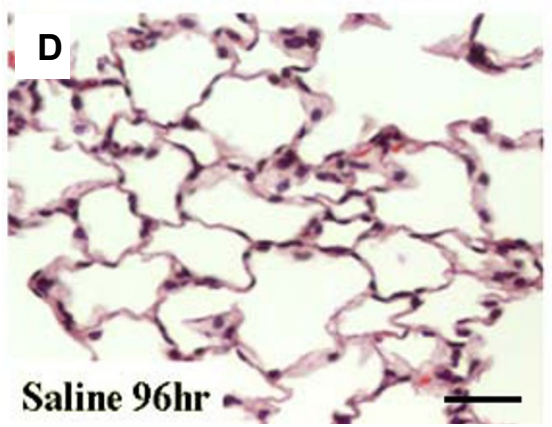

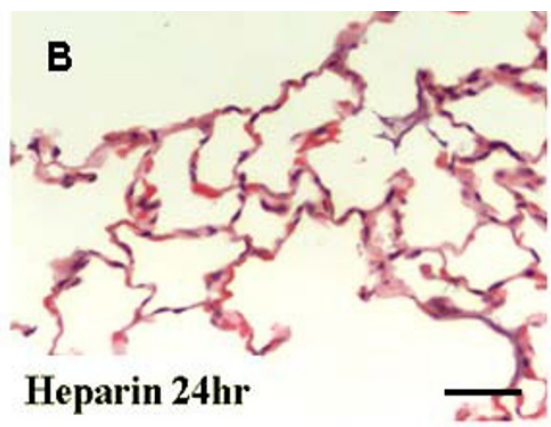
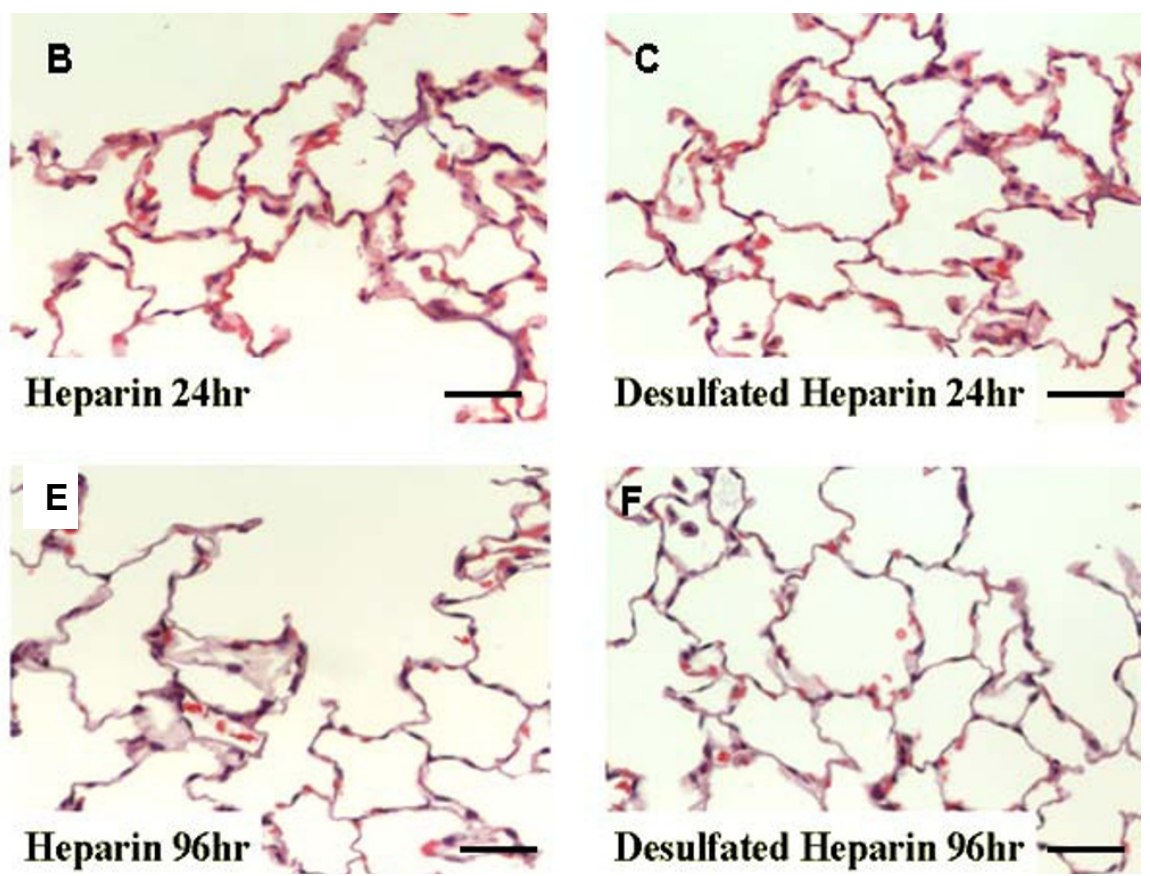

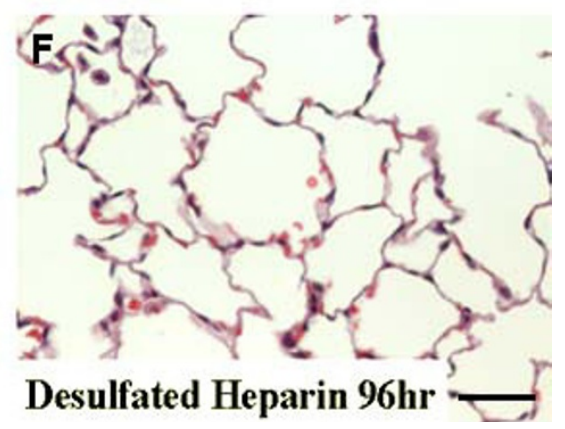

Figure I

Light micrographs depicting representative, random histologic fields from the various treatment groups indicated (A-D). No significant changes in lung architecture, cell infiltrates, or cell numbers were apparent with any of the treatments and the respective time points. Magnification $\times 250$. Bar $=40 \mu \mathrm{M}$. 


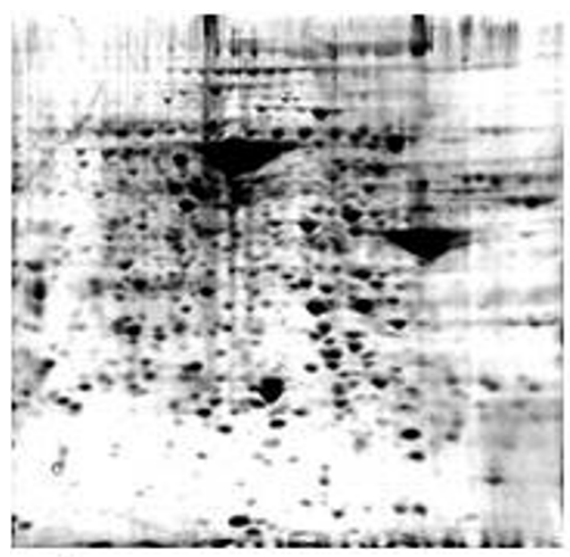

A

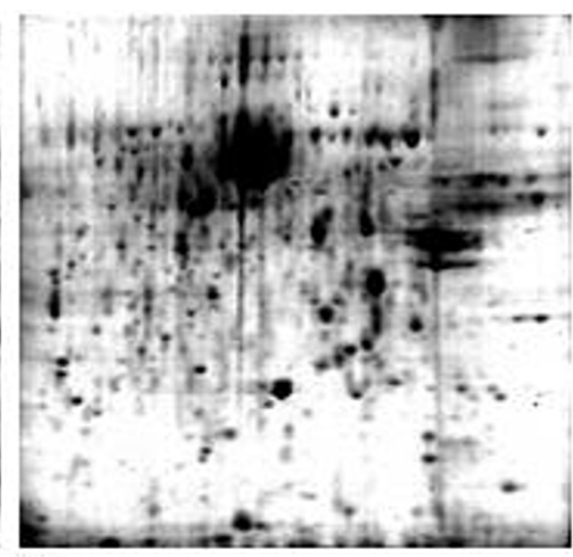

B

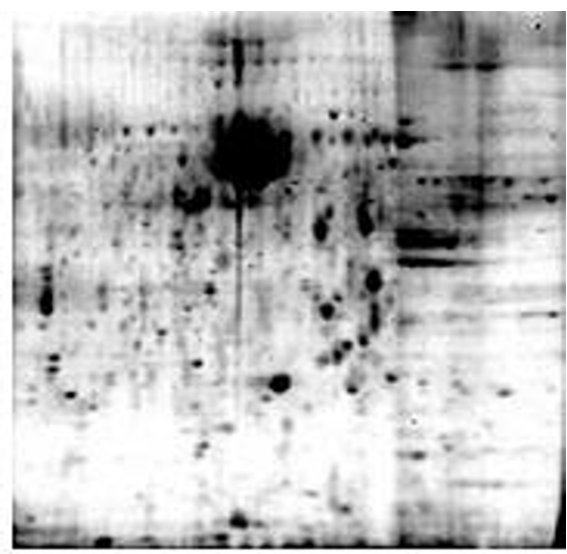

C

pl

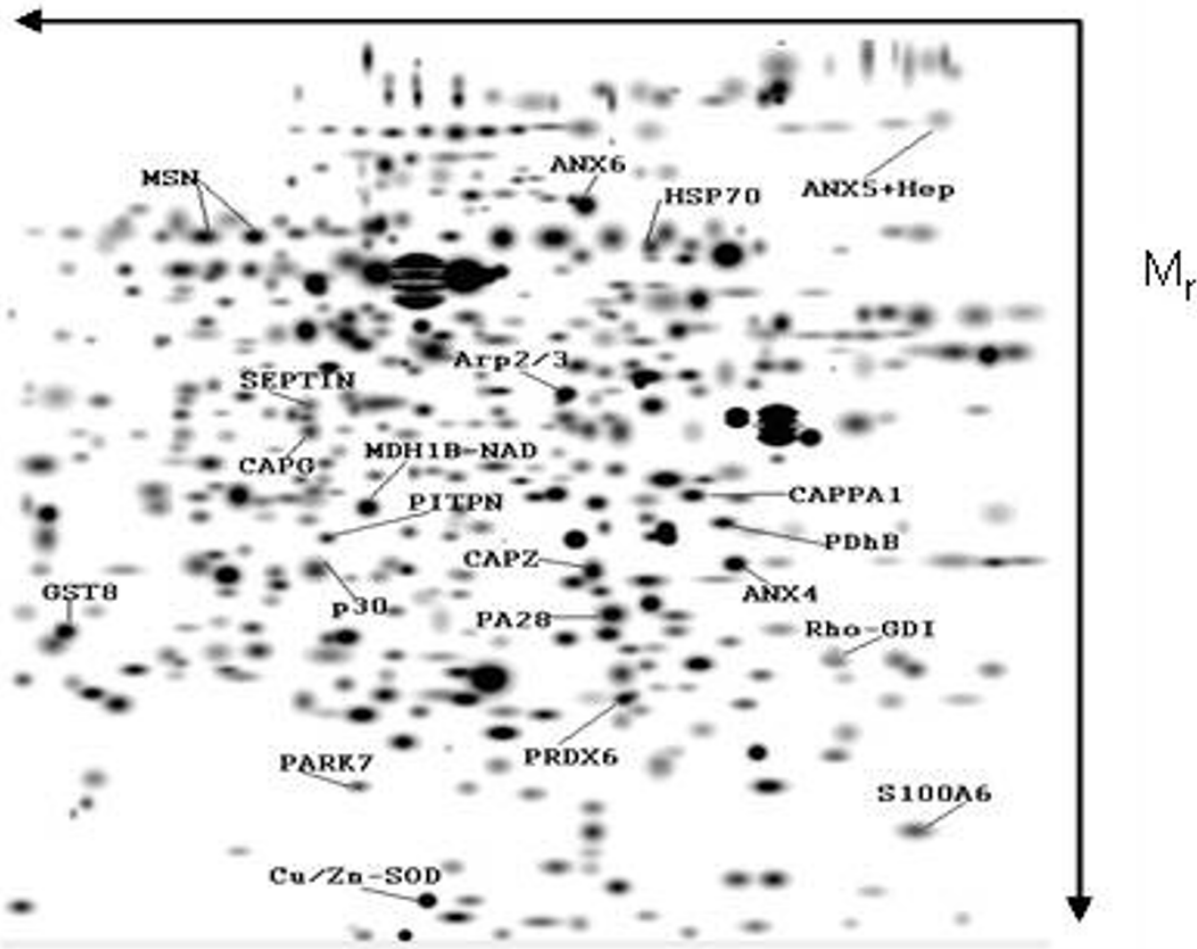

Figure 2

Protein maps representative of each of the treatment sub-groups analyzed in side by side comparison and filtered baseline reference map annotation. A. Control treatment, B. heparin 24 hours, C. heparin 96 hours, and D. a computer analyzed, 2D Gaussian filtered lung reference map with the identified protein spots, separated based on pl and molecular weight (Mr). Note repeatability between sub-groups. 
a lower coefficient of variance per candidate spot, and permitted the combination of the results of similar subgroups for generating reference/group templates. Combining these data sets increased the power of subsequent statistical analyses and aided in the choice of candidate proteins for identification.

\section{Heparin effects on selected proteins from cellular compartments}

The selected protein peptides analyzed by Mass Spectrometry were classified based on the predicted cellular compartmentalization of the native protein (Fig. 3). It is interesting to note that the percentage of cytoskeletonrelated proteins almost doubled among those proteins increased by heparin (Figs. 3A-C). It is understood that some of the larger spots may have masked or otherwise obscured some regulated proteins. However, due to MS limitations of the technique applied in this study (MALDI-TOF/TOF-MS), these proteins spots were not good candidates for quantitative analysis. But it was the purpose of the study to examine those discrete and iden- tifiable proteins whose change in expression exceeded an established threshold (see Methods).

\section{Overall protein expression changes at $\mathbf{2 4}$ hours}

A total of 25 candidate proteins were identified as increased at 24 hours post-heparin treatment and an equal number of candidate proteins were selected due to their significant down-regulation pattern or unchanged status, based on comparisons with the control group gels (Fig. 2). Image analysis confirmed these trends on the pixel level. Protein quantity change was considered significant if expression change was greater than 1.7 -fold ( $\mathrm{p}<$ 0.5 ) (Tables 1 and 2) and CV\% were less than 0.1 . One of the advantages of separating proteins on $2 \mathrm{D}$ gels is the ability to cross-examine MS identifications with protein mobility characteristics. Therefore, the combined results from the image analysis and the MS identification were confirmed by the agreement of mass and iso-electric focusing values calculated via Swiss PDB for the 21 identified proteins satisfying the significance criteria (Tables 1 and 2).
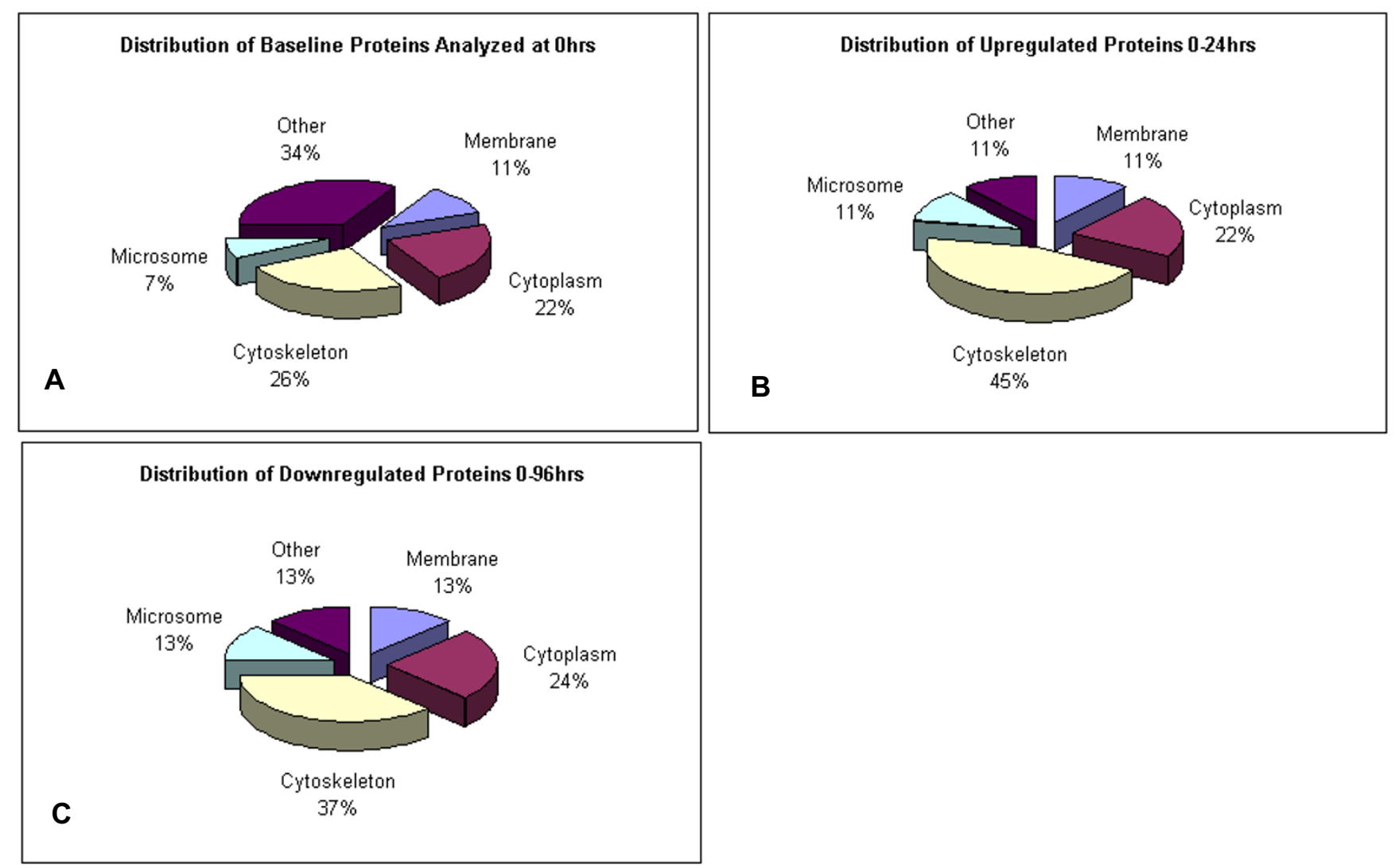

Figure 3

MS identification according to cellular compartment protein expression. A. Percentage of the proteins identified by MS in control lungs with respect to cell compartment. B. Cell compartment distribution of identified increased proteins in heparintreated lungs. C. Distribution of identified reduced proteins in heparin-treated lungs. 
Table I: Increased protein expression profiles

\begin{tabular}{|c|c|c|c|c|c|c|c|c|c|c|}
\hline \multirow[t]{2}{*}{ Protein Identified } & \multirow[t]{2}{*}{ Accession \# } & \multirow[t]{2}{*}{$M_{r} / D$} & \multirow[t]{2}{*}{$\mathrm{pl}$} & \multicolumn{5}{|c|}{ Magnitutde of expression change } & \multirow[t]{2}{*}{$0.96 \mathrm{hr} \mathrm{CV} \%$} & \multirow[t]{2}{*}{ Protein score } \\
\hline & & & & $0.24 \mathrm{hr}$ & $0.24 \mathrm{hr} \mathrm{CV} \%$ & 24.96 & 24.96 hr CV\% & 0.96 & & \\
\hline
\end{tabular}

$0.24 \mathrm{hr} \quad 0.24 \mathrm{hr}$ CV\% $\quad 24.96 \quad 24.96 \mathrm{hr}$ CV\% $\quad 0.96$

Parkinson disease prot.7/Drosophila prot. J-I PARK-7/DJ-I

\begin{tabular}{|c|c|c|c|c|c|c|c|c|c|}
\hline gi|| 6924002 & 19961.4 & 6.32 & $30.05^{*}$ & 0.03 & 0.34 & 0.03 & $10.19 *$ & 0.03 & 108 \\
\hline gi|| 421099 & 10028.3 & 5.3 & $27.00 *$ & 0.12 & 0.48 & 0.03 & $13.02 *$ & 0.02 & 312 \\
\hline gi|34097946 & 61034.1 & 6.2 & $15.02 *$ & 0.05 & 0.73 & 0.05 & $11.00 *$ & 0.05 & 77 \\
\hline gi|| 19435 I6 & 41866.6 & 6.36 & $6.44 *$ & 0.03 & 0.5 & 0.02 & $3.24 *$ & 0.03 & 92 \\
\hline gi||3994I59 & 75706.5 & 6.39 & $6.22 *$ & 0.02 & 0.5 & 0.02 & $3.10 *$ & 0.01 & 313 \\
\hline gi||69240।0 & 41566.3 & 6.15 & $4.19 *$ & 0.02 & 0.24 & 0.02 & 1.00 & 0.02 & 118 \\
\hline gi|| 8605629 & 38744.7 & 6.47 & $4.18^{*}$ & 0.02 & 0.24 & 0.03 & 1.00 & 0.02 & 375 \\
\hline gi|34879484 & 55252.4 & 6.55 & $4.14^{*}$ & 0.02 & 0.5 & 0.02 & $2.07 *$ & 0.01 & 310 \\
\hline gi|8394088 & 28559.1 & 5.77 & $3.98^{*}$ & 0.01 & 0.62 & 0.03 & $2.48^{*}$ & 0.02 & 228 \\
\hline gi|| 3540689 & 6769.8 & 6.16 & $3.12^{*}$ & 0.01 & 0.46 & 0.01 & 144 & 0.01 & 496 \\
\hline gi|5654 I074 & 23392.8 & 6.12 & $2.93 *$ & 0.02 & 0.47 & 0.01 & 1.38 & 0.02 & 77 \\
\hline gi|| 3506725 & 10028.3 & 5.3 & $2.7 I^{*}$ & 0.03 & 0.03 & 0.08 & $0.09 *$ & 0.01 & 121 \\
\hline gi|3।542380 & 62107.7 & 6.1 & $2.24 *$ & 0.05 & 0.2 & 0.3 & $0.45^{*}$ & 0.03 & 205 \\
\hline gi|6679337 & 31873 & 5.97 & $2.03 *$ & 0.02 & 0.44 & 0.01 & 0.90 & 0.02 & 93 \\
\hline gi|20302। I3 & 62530.4 & 6.4 & $2.00 *$ & 0.02 & 0.23 & 0.02 & $0.46^{*}$ & 0.02 & 271 \\
\hline gi|38328483 & 29498.8 & 6.15 & $1.99 *$ & 0.2 & 0.51 & 0.01 & 0.99 & 0.02 & 223 \\
\hline
\end{tabular}

* significant change compared with untreated controls ( $P<0.05$; or greater than 1.7 fold increase)

Protein score - A "score" based on the frequency of a fragment molecular weight found in a protein of a given range of molecular weight. For every database entry scanned, all matching fragments contribute to the final score.

Protein C.I.\% - Confidence interval that the program assigns to the peptide matches to protein. $>95 \%$ score was considered statistically significant. 
Table 2: Reduced protein expression profiles

\begin{tabular}{|c|c|c|c|c|c|c|c|c|c|c|c|}
\hline \multirow[t]{2}{*}{ Protein Identified } & \multirow[t]{2}{*}{ Accession \# } & \multirow[t]{2}{*}{$M_{r} / D$} & \multirow[t]{2}{*}{$\mathrm{pl}$} & \multicolumn{5}{|c|}{ Magnitude of expression change } & \multirow{2}{*}{$\begin{array}{l}0.96 \mathrm{hr} \\
\mathrm{CV} \%\end{array}$} & \multirow{2}{*}{$\begin{array}{l}\text { Protein } \\
\text { score }\end{array}$} & \multirow{2}{*}{$\begin{array}{l}\text { protein } \\
\text { C.I.\% }\end{array}$} \\
\hline & & & & $0.24 \mathrm{hr}$ & $\begin{array}{l}0.24 \mathrm{hr} \\
\mathrm{CV} \%\end{array}$ & 24.96 & $\begin{array}{l}24.96 \mathrm{hr} \\
\text { CV\% }\end{array}$ & 0.96 & & & \\
\hline Transgelin 2 homologue (Sm22 alpha) & gi|34880944 & 29950.9 & 8.72 & $14.00^{*}$ & 0.02 & 1.00 & 0.11 & $14.0^{*}$ & 0.07 & 114 & 100.00 \\
\hline Pyruvate dehydrogenase lipoamide beta & gi|50925725 & 38957 & 6.2 & $7.50 *$ & 0.02 & 0.75 & 0.05 & $5.63^{*}$ & 0.01 & 119 & 100.00 \\
\hline CAPPAI homologue & gi|34859736 & 32889.3 & 5.43 & $3.47^{*}$ & 0.05 & 4.05 & 0.05 & $14.4^{*}$ & 0.03 & 375 & 100.00 \\
\hline Lactate dehydrogenase $b$ & gi $|6981| 46$ & 36589.1 & 5.7 & $3.08 *$ & 0.02 & 1.46 & 0.01 & $4.5 I^{*}$ & 0.02 & 583 & 100.00 \\
\hline $\begin{array}{l}\text { Dimethylarginine Dimethylaminohydrolase } \\
2(D D A H-2)\end{array}$ & gi|46237608 & 29669.4 & 5.66 & $2.75^{*}$ & 0.03 & 0.86 & 0.04 & $2.36 *$ & 0.07 & 203 & 100.00 \\
\hline
\end{tabular}

\footnotetext{
* significant change compared with untreated controls $(\mathrm{p}<0.05$; or greater than 1.7 fold increase)

Protein score - A "score" based on the frequency of a fragment molecular weight found in a protein of a given range of molecular weight. For every database entry scanned, all matching fragments contribute to the final score.

Protein C.I.\% - Confidence interval that the program assigns to the peptide matches to protein. $>95 \%$ score was considered statistically significant.
}

Specific groups of proteins changed by heparin at 24 hours Proteins increased at 24 hours post-heparin treatment fell into four major categories: 1) calcium signaling pathways, 2) cytoskeletal domains, 3) immune responses, and 4) tumor suppression.

A cluster of proteins related to calcium signaling pathways was found to be up-regulated following heparin treatment. Proteomic analysis identified five proteins as upregulated: annexin $\mathrm{V}$ (ANXV) by $>27$-fold, annexin VI (ANXVI) by $>7$ fold, actin related protein 3 (Arp3) by $>4$ fold, moesin (Msn) by $>3$ fold, and calcyclin (Cacy/ S100A6) by $>2.5$-fold (Fig. 4A and Table 1).

Of the cytoskeleton domain proteins, Rho-GDP dissociation inhibitor (Rho-GDI) protein, a key regulator of the Rho-GTPase family was increased by $>3$-fold; septin and capping G (CapG), two proteins known to be involved in actin filament polymerization, were increased by $>5$ fold at 24 hours (Fig. 4B and Table 1). In addition, 2-phosphatidyl inositol phosphate transfer protein (PIPTN), a member of the phosphatidyl-inositol-phosphate(PIP)/ inositol-phosphatidyl-3 (IP3) family, was increased by >2-fold and Hsp70 doubled (Fig. 4B and Table 1). The change in protein expression as a function of optical density of the electrophoretically resolved spot is further demonstrated by Rho-GDI in an enhanced image (Figs. 5). The increase in spot density from control/saline treatment (Fig. 5A) to heparin treatment at 24 hours (Fig. 5B) and 96 hours (Fig. 5C) is visually evident.

Changes in the expression of two proteins related to immune function were also reflected in the 24 hour posttreatment proteome maps. Interestingly, interferon gamma-inducible proteosome regulator IGIP/PA28, an important modulator of immunoproteosome formation and function, was increased nearly 4-fold (Fig. 4C and
Table 1). Proteosome subunit macropain alpha (PSMA$1)$, known to bind and activate proteosomes critical to immune response in the cytosol and nucleus of cells, was increased nearly 2-fold (Fig. 4C and Table 1).

Drosophila protein J-1/Parkinson protein 7 (DJ-1/ PARK7), a negative regulator of PTEN tumor suppressor and a potential prognostic marker for cancer, was increased by $>30$-fold at 24 hours and the tumor suppressor-related protein, hyaluronate binding protein-1 (HABP-1), was increased $>15$ fold (Fig. 4D and Table 1) while transgelin (TAGLN2), was the most significantly down-regulated protein at $>14$-fold (Fig. 4D and Table 2). The change in DJ-1/PARK7 expression is further demonstrated by in-gel enhancement through computer analysis from control/saline treatment (Fig. 6A) compared to heparin treatment at 24 hours (Fig. 6B) and 96 hours (Fig. 6C).

\section{Immunostaining for annexin $\mathbf{V}$}

In order to gain some insight into the cellular localization of upregulated proteins, annexin $\mathrm{V}$ was chosen as a representative example. Figure 7 shows the immunoreactivity for annexin $\mathrm{V}$ in fibroblasts, airway epithelium, macrophages, and alveolar type II cells in the normal rat lung (Fig. 7A). Heparin treatment enhanced immunostaining somewhat (Fig. 7B), with the understanding that immunoreactivity is difficult to truly quantify. Normal serum controls developed no reactive contrast (Fig. 7C).

\section{Overall protein expression changes at $\mathbf{9 6}$ hours}

Lungs at 96 hours post-heparin clearly showed a decrease of many proteins compared to the 24 hours post-heparin group. As with the 24 hour analysis, protein identifications were further confirmed by their agreement with the separation patterns and the $M_{r}$ calculations performed using the Swiss PDB tool (Tables 1 and 2). There was min- 

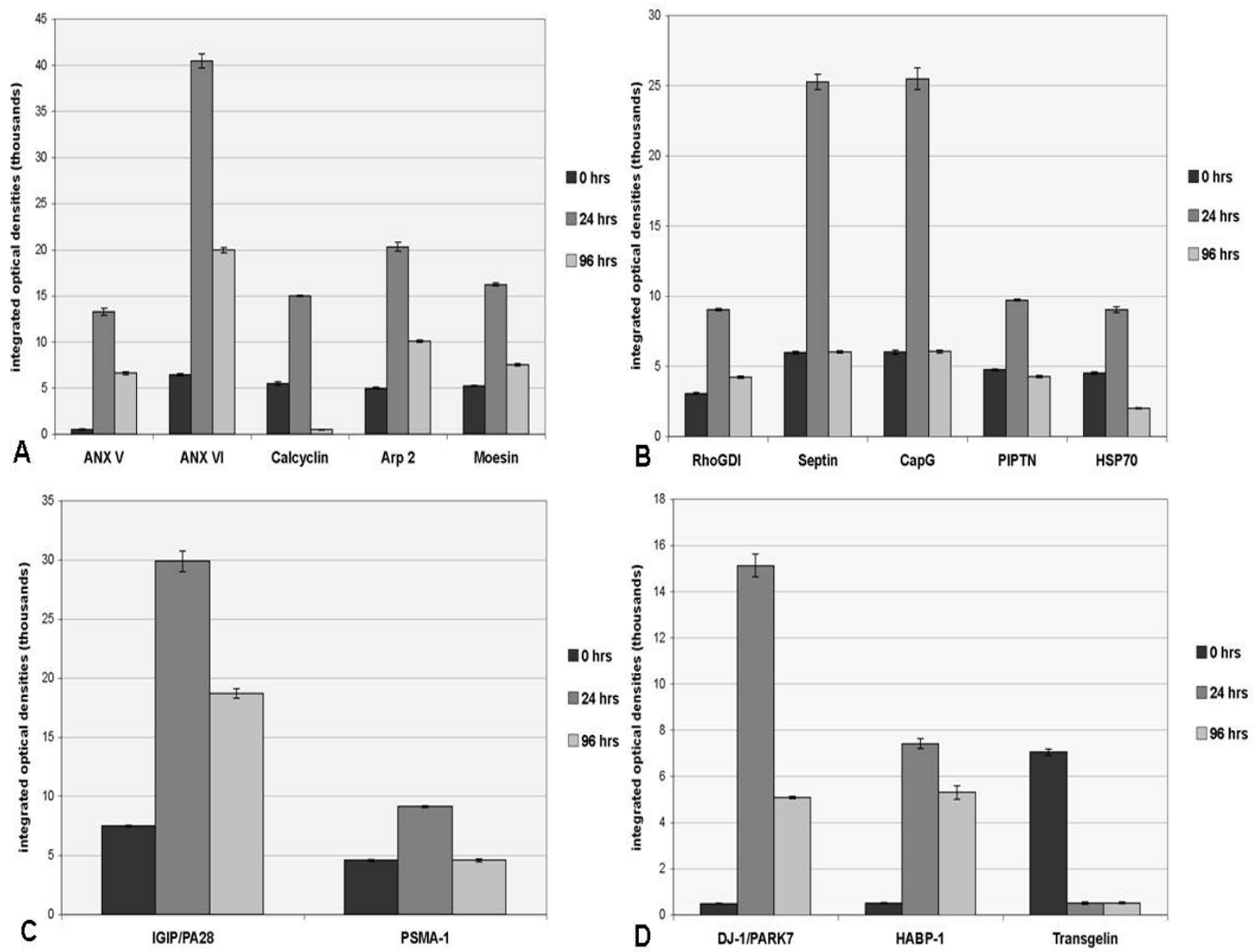

\section{Figure 4}

Graphs of protein spot densities represent the time course of heparin's effects on levels of proteins with the greatest change in expression, as detected in 2D gels and identified by MS, due to heparin instillation in rat lung. A. Calcium signaling pathway proteins indicated increases in ANXV, ANXVI, calcyclin, ARP3, and moesin (Msn) at 24 hours. While by 96 hours all were reduced from 24 hour levels, only calcyclin was reduced to below 0 hour control levels. B. Cytoskeletal domain proteins RhoGDI, septin, CapG, PIPTN, and HSP70 were increased at 24 hours. All decreased to control levels (0 hours) or less by 96 hours. C. Two immune response-related proteins, IGIP/PA28 and PSMA-I, were increased at 24 hours, and decreased by 96 hours. D. Two proteins relating to tumor suppression, DJ-I/PARK-7 and HABP-I, were increased at 24 hours and reduced by 96 hours, while Transgelin was reduced from control levels at 24 hours and remained low through 96 hours after heparin treatment. Note that Arp3 and Msn are found in the cytoskeletal domain as well as being grouped with the calcium signaling proteins but were graphed only once in $A$.

imal statistical difference between the treatment subgroups in expression of the selected proteins, with most being reduced from the 24 hour period. However, most remained elevated above control levels. Those remaining significantly increased at the 96 hour post-heparin time point were ANXV, ANXVI, Arp3 (Fig. 4A and Table 1), IGIP/p28 (Fig. 4C and Table 1), and HABP-1, and DJ-1/ PARK7 (Fig. 4D and Table 1).

\section{Discussion}

This report describes the 2D gel electrophoresis and MS analysis of selected proteins in normal and heparintreated rat lung and identifies proteins that change in quantity 24 and 96 hours after a single in-vivo aerosol exposure to heparin. The twenty most dynamically expressed proteins were selected at the time points tested in the study and further analyzed by MS. They represent potential biomarkers or indicators of cellular/tissue responses to heparin and sort into specific categories that could be useful in a systems biology approach to create a mechanistic model of heparin's actions on whole rat lung.

\section{Calcium signaling pathways}

Based on lung proteome analysis, ANXV, which is a calcium- and phospholipid-binding protein, had the second greatest increase ( $>27$-fold change at 24 hours) and the 
A
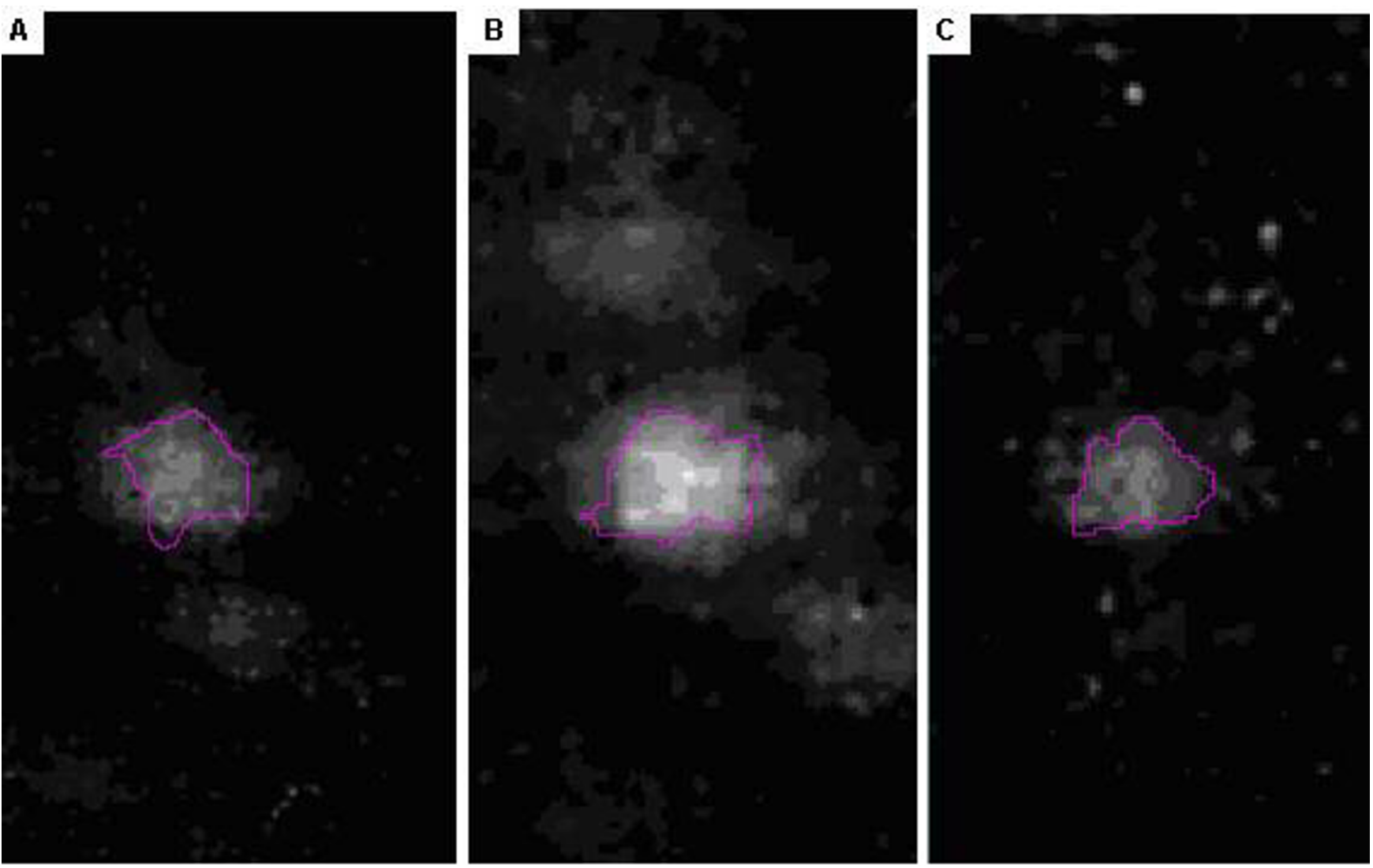

\section{Figure 5}

Illustrated is the expression of Rho-GDI protein stained with Sypro-Ruby across all master group-reference maps. A. Control, B. 24 hrs, and C. 96 hrs post-treatment. The expression of Rho-GDI increased 3+ fold from A to B.

greatest increase overall by 96 hours (>13-fold). Annexins have previously been shown to bind to GAG's in the presence of calcium. Perhaps relatedly, calcyclin (S100A6), another calcium-binding protein, was increased nearly 3fold at 24 hours post-heparin. Calcyclin is known to bind to ANXV in the presence of calcium [18]. The calcyclin+Ca+ANXV complex has been shown to be involved in actin polymerization via the Arp2/3 complex [18-20]; Arp3 was one of the identified proteins increased in this proteomic analysis. Actin polymerization could subsequently enhance the dynamic relocation of cytoskeletonlinking attachment proteins [19] such as moesin, also observed to be increased in this study. These cumulative observations support the notion that heparin treatment of whole lung as in the present study and as has been previously reported in cell cultures $[19,21]$ results in calcium influx into lung cell cytosolic compartments and triggers significant increases in expression or relocation of selected groups of proteins related to cytoskeletal reorganization and immune function.

\section{Cytoskeletal domains}

It has been demonstrated that inhaled heparin can prevent exercise-induced bronchoconstriction in asthma patients [15,17], and there is evidence suggesting heparin's potential in promoting wound healing [22-24] and in preventing lung fibrosis $[13,25,26]$, although the underlying mechanisms involved remain unclear. In this study it was found that a number of cytoskeleton-related proteins were increased at 24 hours post-heparin treatment. Based on bioinformatics and biological data-mining models, these results support the notion that heparin treatment appears to increase selected contractile and structural elements in the lung. Specifically, Rho-GDI protein was found to be increased >3-fold at 24 hours postheparin. Rho-GDI is known to bind the key activator, Ras, 

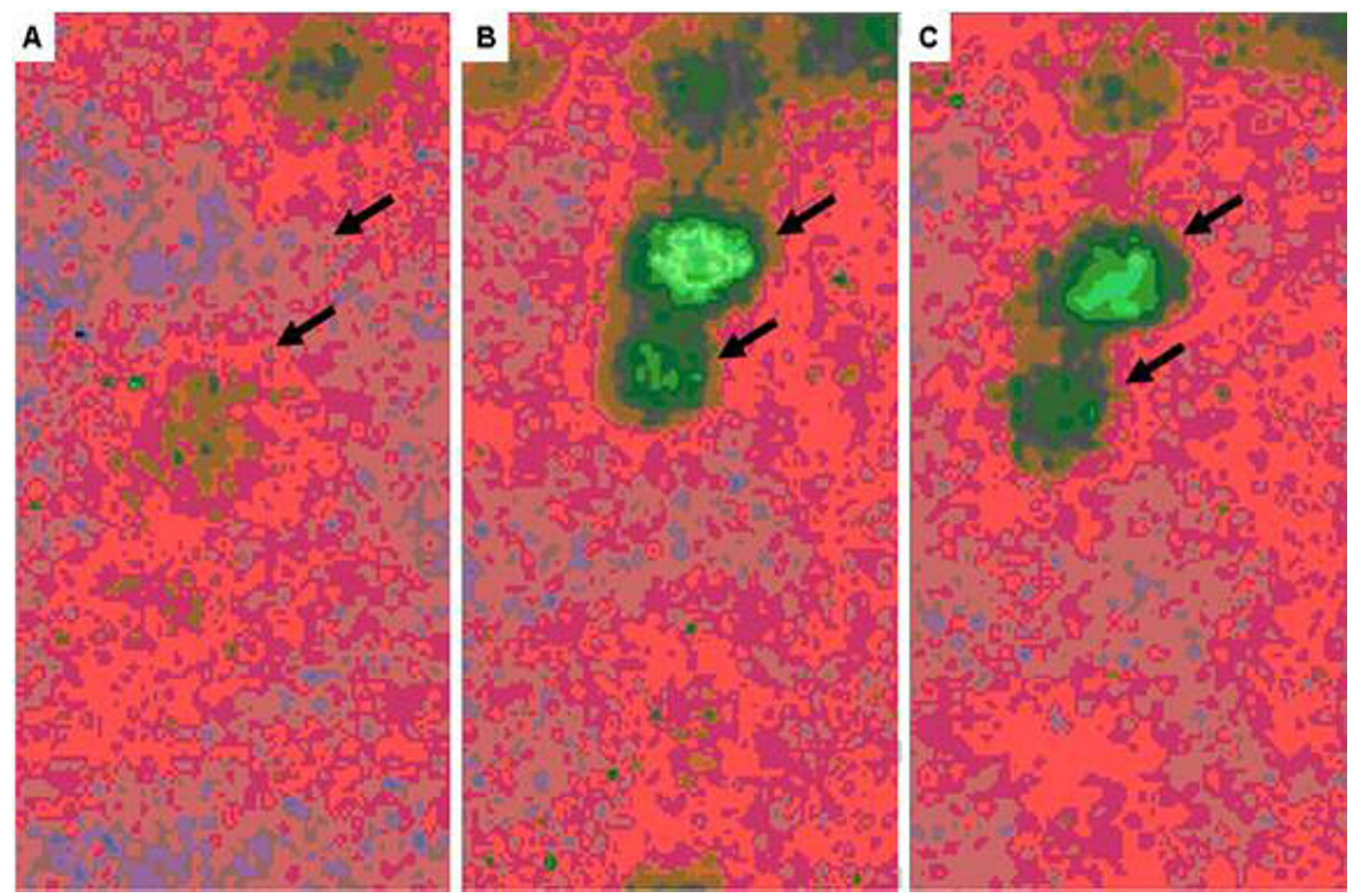

\section{Figure 6}

Pseudocolor density image, of in-gel image comparison of expression change for DJ-I/PARK-7 protein across all group maps. A. Control, B. 24 hrs, C. 96 hrs.

which actuates important cellular events including cellular growth, movement, apoptosis, and immune regulation. The binding is known to be inhibitory of Rac, a small GTPase involved in cytoskeleton contractility [27]. Both events might be expected to reduce/prevent contractile events, such as bronchoconstriction. This same inhibition may promote cellular adhesion events and cytoskeletal stability. Perhaps relatedly, other contractile/cytoskeletal proteins were also found to be increased by heparin. Moesin and PIPTN were up-regulated $>3$-fold and $>2$ fold, respectively, by 24 hours. Moesin and PIPTN enable the cytosolic RhoA/Rho-GDI complex to partially unfold and reveal hydrophobic regions which are able to attach to cell membrane surfaces, and in doing so, release RhoGTP proteins - active in cytoskeletal reorganization [2833]. Moesin, a significant attachment protein, binds to the cell surface HSPG, syndecan-2 [34]. In addition to being implicated in cell migration and actin cytoskeletal reor- ganization, PIPTN - also identified as increased $>2$-fold by heparin - has been shown to independently activate NADPH protein [35]. Receptor stimulation transmitted by Rho and PIPTN activates proteins at the leading edge of migrating cells and recruits other actin-related proteins, such as Arp3 (also increased $>4$-fold by heparin) in complex with Arp2, and actin monomers, to induce actin filament branching and membrane protrusion. This can be accomplished through activation of scaffold proteins called WASp's, which are capable of activating the Arp2/3 complex and promoting actin cytoskeleton polymerization [36]. Polymerization has been shown to accelerate when WASp is in the presence of septin, another protein increased by heparin treatment in the present study (Fig. 3B). It has also been suggested that there are direct relationships among septin, the actin cytoskeleton, and the Rho family of proteins [37]. Another protein increased by heparin was heat shock protein 70, HSP70 ( 2-fold), 

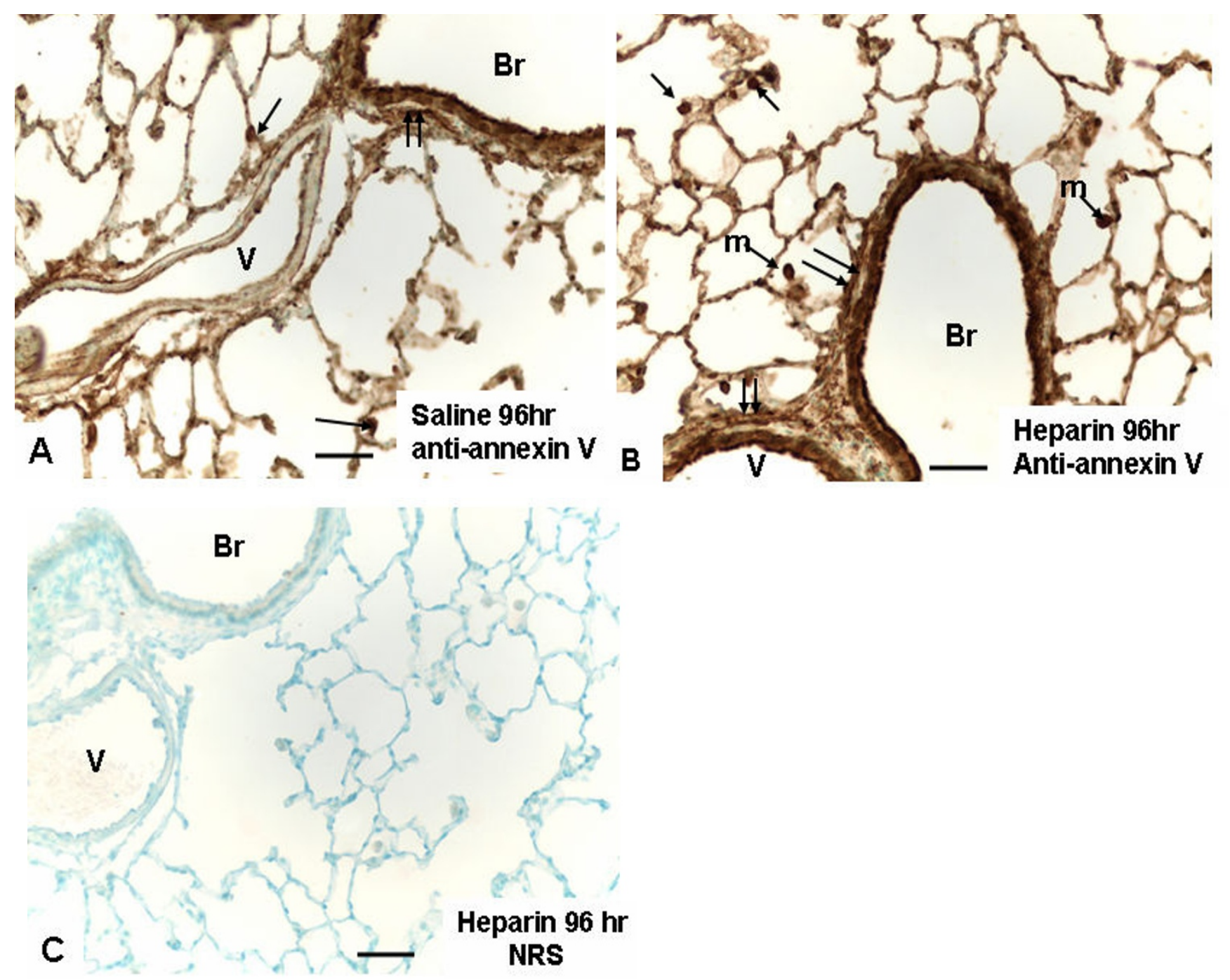

Figure 7

Light micrographs depict representative histologic fields from the various treatment groups indicated (A-C). A. Annexin $V$ immunostaining is seen in bronchiolar $(\mathrm{Br})$ lining epithelium and associated fibroblast layer (double arrows) and alveolar type II epithelial cells (single arrows). Annexin $\mathrm{V}$ is also demonstrated in endothelium in pulmonary vessel (V). Magnification $\times 300$. Bar $=30 \mu \mathrm{m}$. B. Annexin $\vee$ immunostaining from a heparin-treated lung shows similar features to $A$, but with generally an increase in overall staining, including macrophages $(\mathrm{m})$, not depicted in panel A. Magnification $\times 300$. Bar $=30 \mu \mathrm{m}$. C. Histochemical control treated with normal rabbit serum (NRS) in place of rabbit anti-annexin V. Magnification $\times 200$. Bar $=50 \mu \mathrm{m}$.

which mediates cytoprotective effects through its function as a molecular chaperone and through the phosphorylation-dependent stabilization of actin filaments [38].

It's worth noting that the cell type(s) and their numbers with increased expression of cytoskeletal proteins is not known from these studies. Smooth muscle cells and the transition of interstitial fibroblasts to myofibroblasts might be logical sources of the observed increases. Early work suggested that heparin induces smooth muscle actin expression and differentiation of myofibroblasts [39]. More recent studies suggest that heparin in combination with fibroblast growth factors prevent myofibroblast differentiation $[40,41]$ - perhaps more likely a scenario to be expected in an in vivo environment. Expansion of smooth muscle is an even less likely source, since heparin is well recognized for its antiproliferative effects on these cells. Future studies will hopefully clarify this important point and area of investigation.

\section{Immune response}

There is increasing evidence for the anti-inflammatory effects of heparin [5,6,12,42-45]. The current study supports this body of evidence by reporting heparin's effects 
on the expression of two proteins important in the immune response. IGIP/PA28 plays key roles in immune response mechanisms $[46,47]$ and has been shown to act in intracellular immune functions via cytoskeletal membrane trafficking and processing, possibly through its binding to Hook3 protein, an actin-microtubule-binding protein [48]. In concert with the combination of several regulatory events, IGIP/PA28 aids in production of MHC class 1 antigen in interferon gamma-stimulated cells $[49,50]$. Interestingly, heparin and/or IGIP/PA28 also stimulate STAT-1 and STAT-3 pathways, which are antiinflammatory in a number of cell models $[51,52]$. The second protein, PSMA-1, along with IGIP/PA28, activates proteosomes which produce antigenic peptides required for the stimulation of immune responses [50].

\section{Tumor suppression}

DJ-1/PARK7, a negative regulator of the tumor suppressor PTEN and promoter of proliferative pathways and cell survival $[53,54]$, was increased (>30-fold) at 24 hours. It's not clear how this reconciles with heparin's established anti-proliferative effects on cells in general, but may reflect a more specific response that remains to be illucidated. Heparin's known anti-tumor effects may be reflected in our observation that, at 24 hours post-heparin treatment, the tumor suppressor protein HABP-1 is increased $>15$-fold. In addition, transgelin, an actin binding cytoskeletal protein known also to have a role in calcium interactions of smooth muscle cells, was the most significantly reduced protein at 14 -fold. Transgelin is associated with cellular changes in idiopathic pulmonary fibrosis (IPF) and was previously proposed to be a candidate tumor antigen [55-58]. The mechanisms for these changes present intriguing targets for future studies.

\section{Overall protein expression changes at $\mathbf{9 6}$ hours}

It is important to note that nearly half of the proteins detected which related to cytoskeletal reorganization return to nearly baseline/control levels of expression by 96 hours. There was a general decrease in protein expression by 96 hours post-treatment compared to the 24 hours time-point. It is likely that the effects of heparin on most cells decrease with time, since the animals were not retreated. This is consistent with other in vivo and in vitro studies from our lab. Other proteins, like ANXV, ANXVI, IGIP/PA28, and HABP-1, were increased at 24 hours and remained highly elevated at 96 hours - and indication that heparin has more extended effects on selected proteins.

\section{Conclusion}

In the present study, alterations of the rat lung proteome in response to heparin are detailed for the first time. The majority of proteins that were up-regulated were related to calcium signaling and cytoskeletal organization, as evi- denced by the strong increases in ANXV and ANXVI, Msn, RhoGDI, PIPTN, calcyclin, and Arp3. These may serve as potential biomarkers or indicators of baseline response to changes in the lung macro- and/or microenvironments, aiding in further understanding of the lung proteome, in addition to understanding specific organ responses to challenge or stimulation. This, and the indication that other major groups of proteins related to immune function and control of cell growth were also responsive to heparin treatment, suggests that heparin's known suppressive effects upon lung fibrosis and even some cancers may result from its effects upon cell shape and motility, moderation of cell growth, and stimulation of the immune response. This approach may prove useful to future systems biology studies addressing changes to tissue architecture of lung, such as asthma, chronic obstructive lung disease, and cystic fibrosis. Further, these results also raise the possibility that shed surface ectodomains of proteoglycans, as modeled in this study by heparin, may have a broader influence on biological responses in the lung than previously appreciated. Future studies will help clarify this potentially important issue.

\section{Competing interests}

The author(s) declare they have no competing interests.

\section{Authors' contributions}

AG and PS were involved in the concept and design of all experiments, and AG, PS, MR, JP and DN were involved in analysis and interpretation of data. MR, JP, and JK were involved in data acquisition and further analysis. AG and JK were directly responsible for the animal experimentation, AG performed all protein separations, MR and JP performed all mass spectroscopy, and AG analyzed and formatted all data sets. AG, PS, and DN coordinated and prepared the manuscript, which was further edited by MR and JP. All the authors read and approved of the manuscript.

\section{Acknowledgements}

The authors gratefully acknowledge the support of Public Health Service Grant HL-44497 and a grant from the State of North Carolina.

\section{References}

I. Hanash S: Disease proteomics. Nature 2003, 422:226-232.

2. Weston AD, Hood L: Systems biology, proteomics, and the future of health care: toward predictive, preventative, and personalized medicine. J Proteome Res 2004, 3: I 79- 196.

3. Fehniger TE, Sato-Folatre JG, Malmstrom J, Berglund M, Lindberg C, Brange C, Lindberg H, Marko-Varga G: Exploring the context of the lung proteome within the airway mucosa following allergen challenge. J Proteome Res 2004, 3:307-320.

4. Li CM, Newman D, Khosla J, Sannes PL: Heparin inhibits DNA synthesis and gene expression in alveolar type II cells. Am J Respir Cell Mol Biol 2002, 27:345-352.

5. Sannes PL, Khosla J, Cheng PW: Sulfation of extracellular matrices modifies responses of alveolar type II cells to fibroblast growth factors. Am J Physiol 1996, 27 I :L688-697. 
6. Sannes PL, Khosla J, Li CM, Pagan I: Sulfation of extracellular matrices modifies growth factor effects on type II cells on laminin substrata. Am J Physiol 1998, 275:L70I-708.

7. Larsen K, Malmstrom J, Tufvesson E, Marko-Varga G, WestergrenTorsson G: Antiprolilferative heparan sulfate inhibiting hyaluronan and transforming growth factor-b expression in human lung fibroblast cells. Clin Proteomics J 2004, I:27I-284.

8. Malmstrom J, Marchese J, Juhasz P, Pukac L, Karnovsky M, MarkoVarga G, Westergren-Thorsson G: Quantitative proteomic analysis of fibroblast nuclear proteins after stimulation with mitogen activated protein kinase inhibiting heparan sulfate. J Chromatogr B Analyt Technol Biomed Life Sci 2005, 8I 5:333-342.

9. Sasaki M, Kashima M, Ito T, Watanabe A, Sano M, Kagaya M, Shioya $T$, Miura M: Effect of heparin and related glycosaminoglycan on PDGF-induced lung fibroblast proliferation, chemotactic response and matrix metalloproteinases activity. Mediators Inflamm 2000, 9:85-91.

10. Kanabar V, Hirst SJ, O'Connor BJ, Page CP: Some structural determinants of the antiproliferative effect of heparin-like molecules on human airway smooth muscle. $\mathrm{Br} J$ Pharmacol 2005, | 46:370-377.

II. Yu L, Quinn DA, Garg HG, Hales CA: Cyclin-dependent kinase inhibitor p27Kipl, but not p2 IWAFI/CipI, is required for inhibition of hypoxia-induced pulmonary hypertension and remodeling by heparin in mice. Circ Res 2005, 97:937-945.

12. $\mathrm{Xu} \mathrm{J,} \mathrm{Park} \mathrm{PW,} \mathrm{Kheradmand} \mathrm{F,} \mathrm{Corry} \mathrm{DB:} \mathrm{Endogenous} \mathrm{attenua-}$ tion of allergic lung inflammation by syndecan-I. J Immunol 2005, 174:5758-5765.

13. Gunther A, Lubke N, Ermert M, Schermuly RT, Weissmann N, Breithecker A, Markart P, Ruppert C, Quanz K, Ermert L, Grimminger F, Seeger W, I68 V, I I I, I 358 SP, I 365 OP: Prevention of bleomycin-induced lung fibrosis by aerosolization of heparin or urokinase in rabbits. Am J Respir Crit Care Med 2003, 168:1358-1365.

14. Sasisekharan R, Shriver Z, Venkataraman G, Narayanasami U: Roles of heparan-sulphate glycosaminoglycans in cancer. Nat Rev Cancer 2002, 2:521-528.

15. Garrigo J, Danta I, Ahmed T: Time course of the protective effect of inhaled heparin on exercise-induced asthma. Am J Respir Crit Care Med 1996, I 53:1702-1707.

16. Cripps JG, Crespo FA, Romanovskis P, Spatola AF, Fernandez-Botran $\mathrm{R}$ : Modulation of acute inflammation by targeting glycosaminoglycan-cytokine interactions. Int Immunopharmacol 2005, 5:1622-1632.

17. Ahmed T, Garrigo J, Danta I: Preventing bronchoconstriction in exercise-induced asthma with inhaled heparin. $N$ Engl J Med 1993, 329:90-95.

18. Stradal TB, Gimona $\mathrm{M}$ : $\mathrm{Ca}(2+)$-dependent association of SI00A6 (Calcyclin) with the plasma membrane and the nuclear envelope. J Biol Chem 1999, 274:31593-31596.

19. Koulen P, Ehrlich BE: Reversible block of the calcium release channel/ryanodine receptor by protamine, a heparin antidote. Mol Biol Cell 2000, I I:2213-22I 9.

20. Amieva MR, Furthmayr $\mathrm{H}$ : Subcellular localization of moesin in dynamic filopodia, retraction fibers, and other structures involved in substrate exploration, attachment, and cell-cell contacts. Exp Cell Res 1995, 21 9:180-196.

21. Appel RD, Bairoch A, Sanchez JC, Vargas JR, Golaz O, Pasquali C, Hochstrasser DF: Federated two-dimensional electrophoresis database: a simple means of publishing two-dimensional electrophoresis data. Electrophoresis 1996, 17:540-546.

22. Arikan S, Adas G, Barut G, Toklu AS, Kocakusak A, Uzun H, Kemik $O$, Daduk Y, Aydin S, Purisa S: An evaluation of low molecular weight heparin and hyperbaric oxygen treatment in the prevention of intra-abdominal adhesions and wound healing. Am J Surg 2005, 189:155-160.

23. Peplow PV: Glycosaminoglycan: a candidate to stimulate the repair of chronic wounds. Thromb Haemost 2005, 94:4-16.

24. Zcharia E, Zilka R, Yaar A, Yacoby-Zeevi O, Zetser A, Metzger S, Sarid R, Naggi A, Casu B, llan N, Vlodavsky I, Abramovitch R: Heparanase accelerates wound angiogenesis and wound healing in mouse and rat models. Faseb j2005, 19:2 I I-221.

25. Kinder BW, Collard HR, King TE Jr: Anticoagulant therapy and idiopathic pulmonary fibrosis. Chest 2006, 130:302-303.
26. Kubo H, Nakayama K, Yanai M, Suzuki T, Yamaya M, Watanabe M, Sasaki H: Anticoagulant therapy for idiopathic pulmonary fibrosis. Chest 2005, I 28: 1475-I482.

27. Gerthoffer WT: Actin cytoskeletal dynamics in smooth muscle contraction. Can J Physiol Pharmacol 2005, 83:85I-856.

28. Faure J, Vignais PV, Dagher MC: Phosphoinositide-dependent activation of Rho $A$ involves partial opening of the RhoA/ Rho-GDI complex. Eur J Biochem 1999, 262:879-889.

29. Mehta $D$, Rahman $A$, Malik AB: Protein kinase $C$-alpha signals rho-guanine nucleotide dissociation inhibitor phosphorylation and rho activation and regulates the endothelial cell barrier function. I Biol Chem 200I, 276:226I4-22620.

30. Rivero F, Illenberger D, Somesh BP, Dislich H, Adam N, Meyer AK: Defects in cytokinesis, actin reorganization and the contractile vacuole in cells deficient in RhoGDI. Embo J 2002, 21:4539-4549.

3I. Sasaki T, Takai Y: The Rho small G protein family-Rho GDI system as a temporal and spatial determinant for cytoskeletal control. Biochem Biophys Res Commun 1998, 245:64I-645.

32. Sun J, Barbieri JT: ExoS Rho GTPase-activating protein activity stimulates reorganization of the actin cytoskeleton through Rho GTPase guanine nucleotide disassociation inhibitor. J Biol Chem 2004, 279:42936-42944.

33. Takahashi K, Sasaki T, Mammoto A, Takaishi K, Kameyama T, Tsukita $S$, Takai Y: Direct interaction of the Rho GDP dissociation inhibitor with ezrin/radixin/moesin initiates the activation of the Rho small G protein. J Biol Chem 1997, 272:2337I-23375.

34. Granes F, Berndt C, Roy C, Mangeat P, Reina M, Vilaro S: Identification of a novel Ezrin-binding site in syndecan-2 cytoplasmic domain. FEBS Lett 2003, 547:212-216.

35. Weiner OD, Neilsen PO, Prestwich GD, Kirschner MW, Cantley LC Bourne HR: A PtdlnsP(3)- and Rho GTPase-mediated positive feedback loop regulates neutrophil polarity. Nat Cell Biol 2002, 4:509-5।3.

36. Prehoda KE, Scott JA, Mullins RD, Lim WA: Integration of multiple signals through cooperative regulation of the N-WASP. Arp2/3 complex. Science 2000, 290:80I-806.

37. Ito H, Iwamoto I, Morishita R, Nozawa $Y$, Narumiya S, Asano T, Nagata K: Possible role of Rho/Rhotekin signaling in mammalian septin organization. Oncogene 2005, 24:7064-7072.

38. Kodiha M, Chu A, Lazrak O, Stochaj U: Stress inhibits nucleocytoplasmic shuttling of heat shock protein hsc70. Am J Physiol Cell Physiol 2005, 289:CI034-104I.

39. Desmouliere A, Rubbia-Brandt L, Grau G, Gabbiani G: Heparin induces alpha-smooth muscle actin expression in cultured fibroblasts and in granulation tissue myofibroblasts. Lab lnvest 1992, 67:716-726.

40. Greenberg RS, Bernstein AM, Benezra M, Gelman IH, Taliana L, Masur SK: FAK-dependent regulation of myofibroblast differentiation. Faseb / 2006, 20:1006-1008.

4I. Ramos C, Montano M, Becerril C, Cisneros-Lira J, Barrera L, Ruiz V, Pardo A, Selman M: Acidic fibroblast growth factor decreases alpha-smooth muscle actin expression and induces apoptosis in human normal lung fibroblasts. Am J Physiol Lung 2006, 29 I:L87I-L879.

42. Derhaschnig U, Pernerstorfer T, Knechtelsdorfer M, Hollenstein U, Panzer S, Jilma B: Evaluation of antiinflammatory and antiadhesive effects of heparins in human endotoxemia. Crit Care Med 2003, 31: II08-III2.

43. Elsayed E, Becker RC: The impact of heparin compounds on cellular inflammatory responses: a construct for future investigation and pharmaceutical development. J Thromb Thrombolysis 2003, 15:11-18.

44. Lever R, Page C: Glycosaminoglycans, airways inflammation and bronchial hyperresponsiveness. Pulm Pharmacol Ther 200I, 14:249-254.

45. Wang L, Brown JR, Varki A, Esko JD: Heparin's anti-inflammatory effects require glucosamine 6-O-sulfation and are mediated by blockade of L- and P-selectins. J Clin Invest 2002, I I0:127-136.

46. Uthaiah RC, Praefcke GJ, Howard JC, Herrmann C: IIGPI, an interferon-gamma-inducible 47-kDa GTPase of the mouse, showing cooperative enzymatic activity and GTP-dependent multimerization. J Biol Chem 2003, 278:29336-29343.

47. Boehm U, Guethlein L, Klamp T, Ozbek K, Schaub A, Futterer A, Pfeffer K, Howard JC: Two families of GTPases dominate the com- 
plex cellular response to IFN-gamma. J Immunol 1998, 161:6715-6723.

48. Kaiser F, Kaufmann SH, Zerrahn J: IIGP, a member of the IFN inducible and microbial defense mediating $47 \mathrm{kDa}$ GTPase family, interacts with the microtubule binding protein hook3. J Cell Sci 2004, I I 7: 1747-1756.

49. Kloetzel PM: The proteasome and MHC class I antigen processing. Biochim Biophys Acta 2004, 1695:225-233.

50. Rechsteiner M, Hill CP: Mobilizing the proteolytic machine: cell biological roles of proteasome activators and inhibitors. Trends Cell Biol 2005, 15:27-33.

5I. Walton KJ, Duncan JM, Deschamps P, Shaughnessy SG: Heparin acts synergistically with interleukin- I I to induce STAT3 activation and in vitro osteoclast formation. Blood 2002, 100:2530-2536.

52. Daino H, Matsumura I, Takada K, Odajima J, Tanaka H, Ueda S, Shibayama $\mathrm{H}$, Ikeda $\mathrm{H}$, Hibi M, Machii T, Hirano T, Kanakura $Y$ : Induction of apoptosis by extracellular ubiquitin in human hematopoietic cells: possible involvement of STAT3 degradation by proteasome pathway in interleukin 6-dependent hematopoietic cells. Blood 2000, 95:2577-2585.

53. Yang $Y$, Gehrke S, Haque ME, Imai Y, Kosek J, Yang L, Beal MF, Nishimura I, Wakamatsu K, Ito S, Takahashi R, Lu B: Inactivation of Drosophila DJ-I leads to impairments of oxidative stress response and phosphatidylinositol 3-kinase/Akt signaling. Proc Natl Acad Sci USA 2005, I02: | 3670-13675.

54. Kim RH, Peters M, Jang Y, Shi W, Pintilie M, Fletcher GC, DeLuca C, Liepa J, Zhou L, Snow B, Binari RC, Manoukian AS, Bray MR, Liu FF, Tsao MS, Mak TW: DJ-I, a novel regulator of the tumor suppressor PTEN. Cancer Cell 2005, 7:263-273.

55. Solway J, Seltzer J, Samaha FF, Kim S, Alger LE, Niu Q, Morrisey EE, Ip HS, Parmacek MS: Structure and expression of a smooth muscle cell-specific gene, SM22 alpha. J Biol Chem 1995, 270: I3460-13469.

56. Nishida $W$, Kitami $Y$, Hiwada $K$ : cDNA cloning and mRNA expression of calponin and SM22 in rat aorta smooth muscle cells. Gene 1993, 130:297-302.

57. Camoretti-Mercado B, Forsythe SM, LeBeau MM, Espinosa R 3rd, Vieira JE, Halayko AJ, Willadsen S, Kurtz B, Ober C, Evans GA Thweatt R, Shapiro S, Niu Q, Qin Y, Padrid PA, Solway J: Expression and cytogenetic localization of the human SM22 gene (TAGLN). Genomics 1998, 49:452-457.

58. Klade CS, Voss T, Krystek E, Ahorn H, Zatloukal K, Pummer K, Adolf GR: Identification of tumor antigens in renal cell carcinoma by serological proteome analysis. Proteomics 200I, I:890-898.

Publish with Bio Med Central and every scientist can read your work free of charge

"BioMed Central will be the most significant development for disseminating the results of biomedical research in our lifetime. "

Sir Paul Nurse, Cancer Research UK

Your research papers will be:

- available free of charge to the entire biomedical community

- peer reviewed and published immediately upon acceptance

- cited in PubMed and archived on PubMed Central

- yours - you keep the copyright
BioMedcentral 